\title{
Alginate Based Nano Composites for the Removal of Heavy Metals
}

\author{
Rais Ahmad* and Anam Mirza \\ Department of Applied Chemistry, Aligarh Muslim University, India
}

Submission: September 14, 2017; Published: September 22, 2017

*Corresponding author: Rais Ahmad, Department of Applied Chemistry, Aligarh Muslim University, India, Tel: 91-0571-2700920-23; Fax: +91-0571-2400528; Email: rais45@rediffmail.com

Abstract

It is essential to remove toxic and carcinogenic heavy metals from wastewater in order to avoid water pollution. This review paper presents the overview for the performance of various Alginate based nano composites explored for the sequestration of various toxic heavy metals such as $\mathrm{Pb}(\mathrm{II}), \mathrm{Cu}(\mathrm{II}), \mathrm{Cd}(\mathrm{II}), \mathrm{Ni}(\mathrm{II}), \mathrm{Co}(\mathrm{II}), \mathrm{Cr}(\mathrm{II})$ and $\mathrm{Cr}(\mathrm{VI})$. The reports of various literature survey revealed that the alginate based nano composite is an excellent material as an adsorbent for the removal of heavy metals.

Keywords: Heavy metals; Alginate; Nano composite

\section{Introduction}

Heavy metals discharged from various industries like electroplating, leather tanning, paint, textile and dying units are the primary cause of water pollution [1]. They pose serious threats to public health and environment due to their high toxicity, bio accumulative and non-biodegradable behavior $[1,2]$. Therefore, Water purification is emerging as a critical need for the researchers owing to the increasing globalization and urbanization [3].

In recent years, adsorption process has received utmost attention in the field of wastewater treatment [4,5]. Based on practical utility and economy, the development of low-cost and eco friendly adsorbents has attracted extensive interest to the researchers all over the world. Nano composites offers excellent template for the removal of heavy metals due their high specific surface area, small size, and quantum size effect [1]. The prefix 'nano' indicates one billionth or 10-9 units [6,7]. They are the materials whose components are mixed at $\mathrm{nm}$ scale [1].

Various types of biopolymers have been utilized for the removal of heavy metals such as chitosan, cellulose, alginate, dextrin, xanthan gum etc. [8,9]. But among various biopolymers, alginate has displayed an obvious efficiency as a biopolymer for the synthesis of biopolymer based nano composites [10]. Sodium alginate is a water soluble linear natural polysaccharide derived from marine plants [1]. It is composed of alternating blocks of 1-4 linked $\alpha$-L-guluronic and $\beta$-D-mannuronic acid residues [1]. It has excellent hydrophilicity, binding ability, low-cost, non-toxic, biocompatibility and renewability [10]. Mainly due to their biocompatibility and low-cost compared to other polymeric materials, alginate based nano composites have been widely explored for the water treatment $[3,11]$.

\section{Discussion}

Various cost effective alginate based adsorbents have been reported that has been successfully explored for the removal

of toxic and carcinogenic heavy metals. Some of the excellent studies have been reported here. Synthesis of silica modified calcium alginate- xanthan gum hybrid bead composites for the removal of $\mathrm{Pb}(\mathrm{II})$ from aqueous solution has been reported [12]. The synthesis of Alginate-grapheme oxide hybrid gel beads for $\mathrm{Cu}[\mathrm{II}]$ removal from aqueous solution has also been reported [13]. Another research revealed the synthesis of Alginate-alumina-collagen fiber adsorbent for the removal of $\mathrm{Cu}[\mathrm{II}], \mathrm{Cd}(\mathrm{II})$ and $\mathrm{Pb}[\mathrm{II}]$ from aqueous solution [4]. Another study reported the synthesis of Alginate-betonies for the removal of $\mathrm{Pb}[\mathrm{II}], \mathrm{Cd}[\mathrm{II}]$ and $\mathrm{Ni}[\mathrm{II}]$ from aqueous solution [13]. The synthesis of novel sodium alginate supported tetrasodiumthiacalix [4] arenetetrasulfonatenanogel for adsorption of $\mathrm{Cu}[\mathrm{II}], \mathrm{Cd}[\mathrm{II}], \mathrm{Pb}[\mathrm{II}], \mathrm{Co}[\mathrm{II}], \mathrm{Ni}[\mathrm{II}]$ and $\mathrm{Cr}[\mathrm{II}]$ was also reported [8]. Another study revealed the synthesis of Methionine-modified betonies/ Alginate bio nano composite for $\mathrm{Pb}[\mathrm{II}]$ and $\mathrm{Cd}(\mathrm{II})$ removal from aqueous solution [14]. Another study was reported for the synthesis of Halloysite/ 


\section{Recent Advances in Petrochemical Science}

Alginate nano composite beads for $\mathrm{Pb}(\mathrm{II})$ adsorption [15]. Another synthesis of Chitosan/ Alginate nano composite for the removal of $\mathrm{Cr}[\mathrm{VI}]$ from wastewater was also reported [1]. Synthesis of Alginate-Au-Mica bio nano composite for the removal of $\mathrm{Pb}[\mathrm{II}]$ and $\mathrm{Cu}[\mathrm{II}]$ from aqueous solution was also reported [16].

\section{Conclusion}

Water contamination has always been a major problem due to rapid industrialization and globalization. There has always been a need for eco friendly approach for remediation of wastewater from toxic and carcinogenic heavy metals. Biopolymers based nano composite offers extensive help in removing heavy metals from wastewater. The literature survey revealed that Alginate based nano composite has been proved to be an excellent adsorbent in removing toxic heavy metals from wastewater. Hence, the synthesis of Alginate based nano composite appears to be the cost effective and simple alternative for the removal of heavy metals.

\section{References}

1. Gokila S, Gomati T, Sudha PN, Anil S (2017) Removal of the heavy metal ion chromium (VI) using Chitosan and Alginate nano composites. Int. J. Biol. Macromol 104: 1459-1468.

2. Ahmad R, Mirza A (2017) Heavy metal remediation by Dextrin-oxalic acid/ cetyltrimethyl ammonium bromide (CTAB)- Montmorillonite (MMT) nano composite. Groundwater Sustainable Development 4: 57 65.

3. Yu K, Ho J, McCandlish E, Buckley B, Patel R, et al. (2013) Copper ion adsorption by chitosan nano particles and alginate micro particles for water purification applications. Colloids and Surfaces A: Physicochemical and Engineering Aspects 425: 31-41.

4. Kim KH, Keller AA, Yang JK (2013) Removal of heavy metals from aqueous solution using a novel composite of recycled materials. Colloids and Surfaces A: Physicochemical and Engineering Aspects 425: 6-14

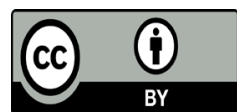

This work is licensed under Creative Commons Attribution 4.0 Licens DOI: 10.19080/RAPSCI.2017.03.555609
5. Ahmad R, Mirza A (2017) Inulin-folic acid/bentonite: A novel nano composite for confiscation of $\mathrm{Cu}(\mathrm{II})$ from synthetic and industrial wastewater. Journal of Molecular Liquids 241: 489-499.

6. Kaushik N, Thakka MS, Snehit S, Mhatre MS, Rasesh Y, et al. (2010) Biological synthesis of metallic nano particles. Nano medicine 6(2): 257-262.

7. Ahmad R, Mirza A (2017) Green synthesis (using plant extracts) of Ag and Au nano particles. Global J Nano med 2(3): 1-2.

8. Lakouraj MM, Mojerlou F, Zare EN (2014) Nano gel and super paramagnetic nano composite based on sodium alginate for sorption of heavy metal ions. Carbohydrate Polymers 106: 34-41.

9. Ahmad R, Mirza A (2017) Green synthesis of xanthan gum/Methioninebetonies nano composite for sequestering toxic anionic dye. Surf Interf 8: 65-72.

10. Monier M, Alatawy RA, Abdel-Latif DA (2015) Synthesis and characterization of uranyl ion-imprinted microspheres based on amidoximated modified alginate. Int J Biol Macromol 75: 354-363.

11. Algothmi WM, Bandaru NM, Yu Y, Shapter JG, Ellis AV (2013) Alginategraphene oxide hybrid gel beads: An efficient copper adsorbent material. Journal of Colloid and Interface Science 397: 32-38.

12. Zhang S, Xu F, Wang Y, Zhang W, Peng X, et al. (2013) Silica modified calcium alginate- xanthan gum hybrid bead composites for the removal and recovery of $\mathrm{Pb}(\mathrm{II})$ from aqueous solution. Chemical Engineering Journal 234: 33-42.

13. Tzu TW, Tsuritani T, Sato K (2013) Sorption of Pb(II), Cd(II) and Ni(II) toxic metal ions by Alginate-betonies. Journal Environment Protection 4: 51-55.

14. Ahmad R, Mirza A (2015) Sequestration of heavy metal ions by Methionine-modified betonies/ Alginate (Meth-bent/Alg): A bio nano composite. Groundwater Sustainable Development 1: 50-58.

15. Chiew CSC, Yeoh HK, Pasbakhsh P, Krishnaiah K, Poh PE, et al. (2016) Halloysite/alginate nanocomposite beads: kinetics, equilibrium and mechanism for lead adsorption. Applied Clay Science 119(2): 301-310.

16. Ahmad R, Mirza A (2017) Adsorption of $\mathrm{Pb}(\mathrm{II})$ and $\mathrm{Cu}(\mathrm{II})$ by Alginate$\mathrm{Au}-\mathrm{Mica}$ bionanocomposite: kinetic, isotherm and thermodynamic studies. Process Safety Environment Protection 109: 1-10.

\section{Your next submission with Juniper Publishers will reach you the below assets}

- Quality Editorial service

- Swift Peer Review

- Reprints availability

- E-prints Service

- Manuscript Podcast for convenient understanding

- Global attainment for your research

- Manuscript accessibility in different formats

( Pdf, E-pub, Full Text, Audio)

- Unceasing customer service

Track the below URL for one-step submission https://juniperpublishers.com/online-submission.php 